\title{
Assessment of reserves and resources of technogenic complexes of gold-bearing deposits using remote sensing methods on the example of the Kerbinsky gold-bearing region (Khabarovsk Region)
}

\author{
Victor Litvintsev ${ }^{1}$, Vitaly Usikov $^{1}$, Yulia Ozaryan ${ }^{1 *}$ and Vladimir Alekseev ${ }^{1}$ \\ ${ }^{1}$ Mining Institute FEB RAS, 51 Turgenev st., Khabarovsk, 680000, Russia
}

\begin{abstract}
Technogenic complexes of placer deposits, the development of which has been completed, are a significant reserve of the mineral resource base of gold and other precious metals. This paper presents the results of the creation of a method for expert assessment of spatial and volumetric indicators of technogenic complexes of alluvial deposits and other landscape objects using remote sensing of the territory and analysis of geological information. The Kerbinsky gold-bearing region of the Khabarovsk Region was chosen as the object of research.
\end{abstract}

\section{Introduction}

One of the main areas of subsoil use in the Far Eastern Federal District is the development of alluvial gold deposits. In the Khabarovsk Region $90 \%$ of gold and all platinum is mined from alluvial deposits. Gold mining in the Khabarovsk Region has been going on for over 130 years, the largest deposits of placer gold are located here, which determined the industrial focus of the region [1]. To increase the resource base and the extraction of precious metals, technogenic formations should be involved in operation using new technologies and equipment. According to view of experts, in the technogenic placers of the region there are reserves of fine gold that can extend the activities of the mining companies for more than 10 years [2].

During the development of gold deposits in the Far East, more than 15,000 hectares of land are annually disturbed, more than $2 / 3$ of which falls on placer deposits. In general, for the gold mining companies of the Far Eastern region, the tendency of accumulation of lands disturbed by mining continues, but the rate of reclamation is low $(0.01 \%)$, and in recent years it has practically not been carried out. There is a constant accumulation of land on the balance sheet of the mining companies. A common characteristic feature of technogenic formations of gold-bearing placers in the Far East is the accumulation of precious metal in them of almost all size classes and morphological forms, including those that are not taken into account by subsoil users during geological exploration $[3,4]$. In the Far East region rich geogenic placers have already been worked out and at present, placer gold reserves are concentrated in deep-

* Corresponding author: ozaryanigd@gmail.com 
lying and technogenic deposits [5]. The first of them are characterized by complex structure, increased clay content in formations and in dump complexes, and a high overburden ratio. The second is the predominance of fine fractions of the useful component and a significant averaging of the metal content over the dump volume. Therefore, a scientific search is needed in the creation of new, promising technologies for the development of deposits and equipment for the enrichment of minerals, as well as the identification of priority technogenic objects of placer gold mining.

Thus, the relevance of studies aimed at processing man-made dumps and assessing the possibility of restoring vegetation to reduce the disturbed areas is obvious.

\section{Methodology and research objects}

When assessing the state of the natural environment in the alluvial gold mining areas of the Khabarovsk Region we used multi-temporal multispectral satellite images of the Landsat series. Single-band and multi-band raster layers were extracted from them and on the basis of that virtual rasters were built. To identify an effective and reliable method for detecting disturbed mining lands first of all the most informative spectral image channels were considered. It makes possible to identify technogenic areas.

To implement the GIS-technology of data processing a geographic database "Cartographic database FE-MI GIS" was created. It was developed for the using it in various computer applications that implement GIS technologies [6].

As part of the methods of Earth remote sensing (ERS) a forecast of natural restoration of vegetation in one of the gold-placer regions of the Khabarovsk Region. The work was performed using the "VEGA-Science" satellite monitoring service to substantiate models of landscape-geochemical stability and environmental capacity of the natural environment.

The VEGA service was created by the Space Research Institute of the Russian Academy of Sciences to assess the state of forest and agricultural resources, but as can be seen from the results of its application it also successfully works to assess problems in geoecology.

\section{Results and discussion}

The disadvantages of technologies for mining gold from placers in the XX century and, as a consequence, the high content of metal in numerous technogenic complexes of placer deposits made it urgent to solve scientific and technological problems in assessing their resources and subsequent development. A significant reduction in gold production from geogenic placers makes it possible to characterize the identified reserves and resources of gold in man-made placers as the most important and real reserve for increasing the production of placer gold.

This paper presents the results of the creation of a method for expert assessment of spatial and volumetric indicators of technogenic complexes of placer deposits and other landscape objects using remote sensing. The Kerbinsky gold-bearing region of the Khabarovsk Region was chosen as the object of research. This area is located on the eastern edge of the YankanoTukuringro-Dzhagdinsky uplift.

High-resolution images clearly decipher the main objects of the industrial infrastructure of the mining area, including the worked-out and under development alluvial gold deposits (Fig. 1). During periods of cessation of mining natural restoration is recorded in the workedout areas.

To assess the prospects for obtaining spatial and volumetric data of technogenic deposits satellite images were decoded in order to identify the worked-out gold-placer areas of the Kerbinsky gold-placer region. The total area of the developed territories is at least 3600 
hectares. The area is $6075 \mathrm{~km}^{2}$. The most productive are placer of Semi River, Gongren River, Kerby River and others. In the central part of the region the growths have been practically worked out and some of them have been transferred to the category of technogenic. Mainly, placers with low gold grades or buried ones remained. In total, $52252 \mathrm{~kg}$ of gold were mined in the Kerbinsky region, there are $2591 \mathrm{~kg}$ of explored reserves, and 35.1 tons of forecasted reserves (Table 1). The gold content in the placers ranges from 86 to $962 \mathrm{mg} / \mathrm{m}^{3}$. The area is characterized exclusively by the density of placer gold content: area $-5.8 \mathrm{~kg} / \mathrm{km}^{2}$, linear - by reserves $-65.7 \mathrm{~kg} /$ liner $\mathrm{km}$, according to predicted resources $455.3 \mathrm{~kg} /$ liner $\mathrm{km}$.

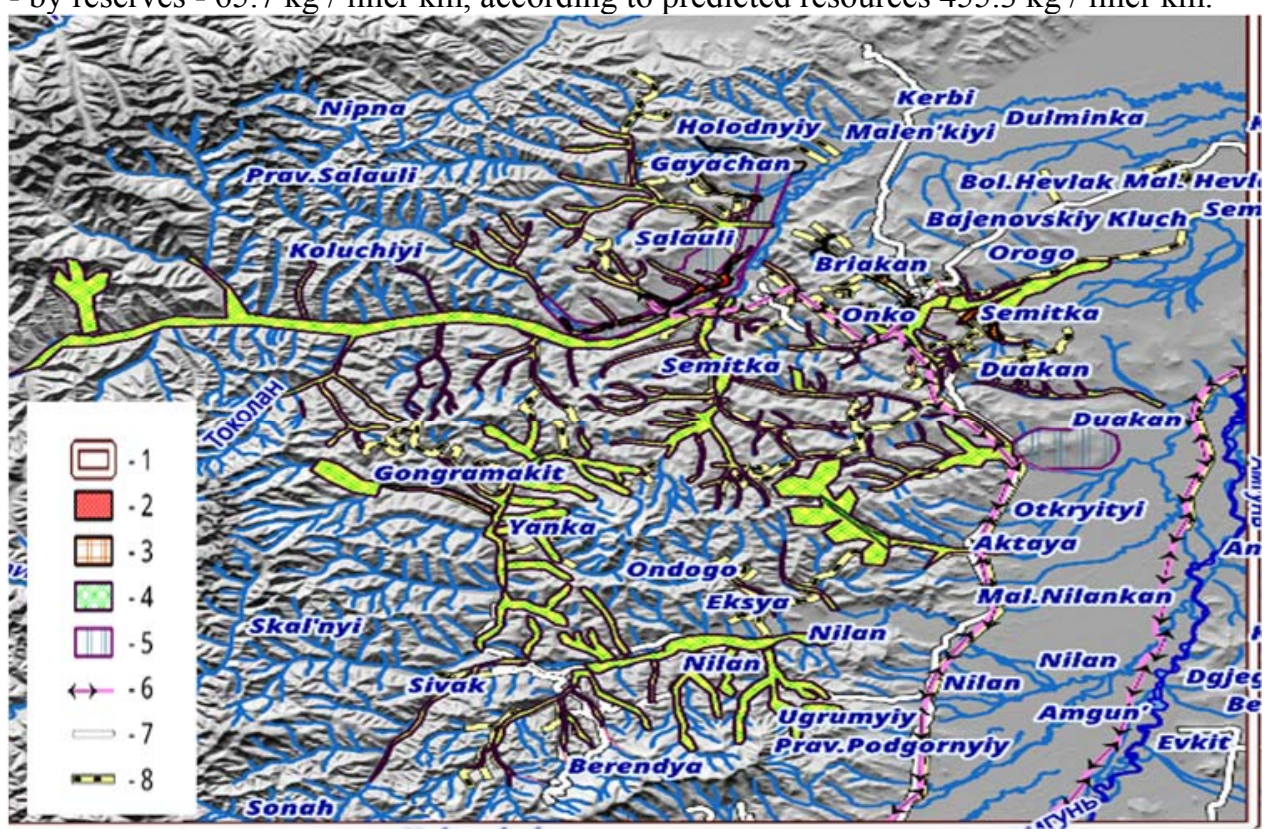

1 - Investigated area; technogenic formations: 2 - Landfills of combined separate mining; 3 - Landfills for hydraulic development; 4 - Dredge and hydraulic mining sites are not separated; 5 - Areas of exploration work; Infrastructure objects: 6 - Power transmission lines; 7 - Roads marked on the topographic map; 8 - Roads established based on the interpretation of images. 2 - 6 and 8 are determined from satellite images.

Fig.1. Map of the Kerbinsky gold-placer area. Basis: Digital elevation model based on DEM SRTM03.

Table 1. Geological and industrial characteristics of the gold-placer Kerbinsky region and, in general, the characteristics of the gold-placer regions of the Khabarovsk Region.

\begin{tabular}{|c|c|c|c|c|c|c|}
\hline \multicolumn{5}{|c|}{ Geological and industrial characteristics } & \multirow[b]{2}{*}{$\begin{array}{l}\text { Total length of } \\
\text { placers: км }\end{array}$} & \multirow[b]{2}{*}{$\begin{array}{c}\text { Linear density of } \\
\text { placers: } \\
\text { Reservesand } \\
\text { resourses } \\
\mathrm{kg} / \text { liner } \mathrm{km}\end{array}$} \\
\hline $\begin{array}{l}\mathrm{C}_{1} \\
\mathrm{~kg}\end{array}$ & $\begin{array}{l}\mathrm{P}_{1-3} \\
\mathrm{~kg}\end{array}$ & $\begin{array}{l}\text { Average } \\
\text { gold content: } \\
\text { Min-max, } \\
\mathrm{mg} / \mathrm{m}^{3}\end{array}$ & Gold, kg & $\begin{array}{l}\text { Size of the } \\
\text { area, } \mathrm{km}^{2}\end{array}$ & & \\
\hline \multicolumn{7}{|c|}{ Gold alluvial areas of the Khabarovsk Region, total } \\
\hline 29390 & 189327 & $\frac{237,1}{50-5670}$ & 292218 & 90960 & $\frac{1243,7}{386,1}$ & $\frac{258,5}{832,8}$ \\
\hline \multicolumn{7}{|c|}{ Kerbinsky gold-bearing region } \\
\hline 2591 & 35100 & $\frac{380}{86-962}$ & 52252 & 6075 & $\frac{77,1}{39,4}$ & $\frac{455,3}{65,7}$ \\
\hline
\end{tabular}


According to the available data [7], it is possible to find deep-lying placers along the tributaries of the Semi River, however, they are characterized by high water cut, low hypsometric position and considerable depth (up to $30 \mathrm{~m}$ ), which complicates development. Technogenic placers along the Semi, Sulakitkan, Botoon Rivers are practical interest. About 30 tons of gold were mined in total. The predicted resources for these technogenic placers (taking into account the technological losses of $15 \%$ during the development of the corresponding natural placers) are more than 5 tons, but the probable content is low (at the level of $80 \mathrm{mg} / \mathrm{m}^{3}$ ). Many geogenic dews of the node are characterized by high clay content and fine gold. During their washing, a significant part of the clay is washed out, which is a favorable factor in the involvement of these objects in secondary processing.

Kerby River valley on the site from the Kut River to the Maklan River is characterized by industrial gold content, but gold is extremely unevenly distributed: there are nests with a very high content and very low. Average gold content by weight is about $50 \mathrm{mg} / \mathrm{m}^{3}$. The dredging process gives the alluvium coefficient of 0.43 . Terrace placers along the Kerby River are also characterized by very difficult mining conditions and insignificant resources $[6,7]$.

The reprocessing of gale-effelike dumps contributes to a significant transformation of the landscape-geochemical conditions formed during the primary processing, due to the withdrawal and repeated movement of large masses of rocks and natural waters within the mining allotment. Technogenic pollution of the territory of mining and industrial development is determined by the composition of rocks and the technology of mining and processing of minerals. The Semi, Sulakitkan, Kerbi, Nilan Rivers are located in technogenically created valleys, represented by a complex of open and vegetated dumps up to $5 \mathrm{~m}$ high, artificial reservoirs, channels.

The results of the research by A.P. Van-Van-E with the creation of a methodology for calculating the resources of technogenic placers are needed for our research.

Table 2. Characteristics of the estimated resources of technogenic placer rocks in the Kerbinsky goldplacer region

\begin{tabular}{|c|c|c|c|c|c|c|c|c|}
\hline River placers & $\begin{array}{c}\text { Average } \\
\text { gold } \\
\text { grade by } \\
\text { weight, g } \\
/ \mathrm{m}^{3}\end{array}$ & $\begin{array}{c}\text { Reworke } \\
\mathrm{d} \text { mining } \\
\text { mass, } \\
\text { thousand } \\
\mathrm{m}^{3}\end{array}$ & $\begin{array}{l}\text { Gold } \\
\text { reserve } \\
\mathrm{s} \text { in } \\
\text { mined } \\
\text { blocks, } \\
\mathrm{kg}\end{array}$ & $\begin{array}{c}\text { Gold } \\
\text { mined } \\
\text { in } \\
\text { mined } \\
\text { blocks, } \\
\text { kg } \\
\end{array}$ & $\begin{array}{c}\text { Lavage } \\
\text { coeffici } \\
\text { ent }\end{array}$ & $\begin{array}{c}\text { Resorses } \\
\text { of } \\
\text { technoge } \\
\text { nic } \\
\text { placer, } \mathrm{kg}\end{array}$ & $\mathrm{C}_{\mathrm{vr}}^{*}$ & $\begin{array}{l}\text { Mining } \\
\text { method }^{* *}\end{array}$ \\
\hline Kamakan & 0,29 & 6300 & 1827 & 2064 & 1,13 & 914 & 0,44 & $\mathrm{O}$ \\
\hline Kerbi & 0,12 & 5135 & 563 & 627 & 1,12 & 281 & 0,45 & $\mathrm{O}, \mathrm{D}$ \\
\hline Gongrena & 0,16 & 5844 & 935 & 695 & 0,74 & 467 & 0,67 & $\mathrm{D}$ \\
\hline Botoon & 0,36 & 9040 & 3254 & 3141 & 0,97 & 1627 & 0,52 & $\mathrm{O}, \mathrm{D}$ \\
\hline Nilamakit & 0,25 & 3480 & 870 & 1043 & 1,2 & 435 & 0,42 & $\mathrm{O}, \mathrm{D}$ \\
\hline Semi & 0,39 & 33449 & 13045 & 15945 & 1,22 & 6522 & 0,41 & $\mathrm{O}, \mathrm{D}$ \\
\hline Sulakitkan & 0,34 & 32600 & 11084 & 11407 & 1,03 & 5542 & 0,49 & $\mathrm{O}, \mathrm{D}$ \\
\hline Briakan & 0,26 & 6160 & 1602 & 2135 & 1,33 & 801 & 0,38 & $\mathrm{O}$ \\
\hline Nilan-1 & 0,23 & 6920 & 1592 & 1942 & 1,22 & 796 & 0,41 & $\mathrm{O}$ \\
\hline Nulgirikan & 0,25 & 2800 & 700 & 832 & 1,19 & 350 & 0,42 & $\mathrm{O}$ \\
\hline M. Tokolan & 0,4 & 1718 & 687 & 804 & 1,17 & 344 & 0,43 & $\mathrm{O}$ \\
\hline Total: & 0,2625 & 118049 & 37264 & 41760 & 1,12 & 18079 & - & - \\
\hline
\end{tabular}

${ }^{*} \mathrm{C}_{\mathrm{vr}}$ is the ratio of the volume of mined gold to the corresponding technogenic resources

${ }^{* *}$ Development method: O - open (hydraulic), U - underwater (dredges)

According to the developed method [9], he calculated the resources of technogenic placers in the Khabarovsk Region, including the Kerbinsky ash-alluvial area. In this gold placer region the resources of technogenic placers were calculated for the deposits of the 
rivers: Kamakan, Kerbi, Gongrena, Botoon, Nilamakit, Semi, Sulakitkan, Briakan, Nilan-1, Nulgirikan and M. Tokolan Rivers.

The average gold content in the placers was $0.2625 \mathrm{~g} / \mathrm{m}^{3}$ (from 0.1 to 0.4 ), 118,049 thousand $\mathrm{m}^{3}$ of rock mass was processed, the gold reserves in the mined placers were 37,264 $\mathrm{kg}$, and mined gold in the mined blocks is $41760 \mathrm{~kg}$. The average reclamation rate was 1.12 (from 0.74 to 1.33). The estimated gold resources of the technogenic placers of the Kerbinsky Region amounted to $18079 \mathrm{~kg}$ (from 281 to $6522 \mathrm{~kg}$ ). The largest resources of technogenic gold are determined at the deposit of the Semi River $(6522 \mathrm{~kg})$ and at the field of the Sulakitkan River $(5542 \mathrm{~kg})$. Gold mining in the Kerbinsky gold-placer region was carried out in two ways - open (hydraulic) and underwater (dredges). Table 2 shows the characteristics of the estimated resources of technogenic placers in the Kerbinsky gold-placer region of the Khabarovsk Region [8, pp. 189-190].

\section{Conclusions}

Thus, using remote sensing methods, decoding high-resolution satellite images and analyzing mining and geological information, data were obtained that made it possible to assess the resources of technogenic complexes of a number of productive placers of the Kerbinsky goldplacer cluster.

\section{References}

1. The main directions of involving the technogenic formations of placer gold in the operation. - URL: https://zolotodb.ru/article/12025 (date of access: 27.07.2020)

2. Resolution of the Khabarovsk Territory Administration: On the main directions of involving industrial formations of dewy gold into operation. DECREE of the Head of the Khabarovsk Territory Administration dated May 30, 2000 No. 180

3. V.S. Alekseev, T.S. Banshchikova, Gornyi Zhurnal, 10, $52-57$ (2018)

4. V.S. Litvintsev, G.P. Ponomarchuk, T.S. Banshchikova, GIAB, Special edition Dalny Vostok, 319-327 (2005)

5. Yu.A. Ozaryan, P.P. Sas, V.I. Usikov, Mine survey and subsoil use, 4(102), 17-21 (2019)

6. V.I. Usikov, L.N. Lipina, M.B. Bubnova, Yu.A. Ozaryan, Certificate of registration of the database 2019620201 Rus. Federation. MI-FE GIS Cartographic Database; copyright holder FSBSI IGD FEB RAS. Declared 01/17/2019; register January 31, 2019.

7. A.P. Sorokin, A.P. Van-Van-E, Yu.A. Mamaev, V.S. Litvintsev, E.A. Sheveleva, I.S. Peltsman, V.D. Glotov, L.V. Belousova, Atlas of multifactor mining and geological models of gold-bearing deposits of the Far East. Actual problems of increasing the efficiency of integrated development of mineral deposits in the Far East: Sat. scientific. (Proc. IGD FEB RAS Vladivostok: Dalnauka, 1999)

8. Van-Van-E A.P. Resource base of natural-man-made gold-and-dust deposits. (M. Publishing house "Gornaya kniga", 2010) 